\title{
Pembentukan Manhaj Jamaah Dalam Pengembangan Masyarakat Islam
}

\author{
Icol Dianto \\ Fakultas Dakwah dan Ilmu Komunikasi IAIN Padangsidimpuan \\ (E-mail: icoldianto@gmail.com)
}

\begin{abstract}
Islam as the religion of rahmatanlil'alamin means that Islam is universal and flexible to all aspects of life, including the life of mankind. Da'wah of Islam touches on the development of the resources of the Muslim community and the global community in humanizing humans, achieving a decent standard of living materially and immaterial (hasanah fid-dunya wal akhirat). However, the availability of potential natural resources has not been maximally utilized because of the low capacity and weak work ethic. Therefore, the establishment of Manhaj Jama'ah in development and empowerment activities is important to implement. Development that is centered on pilgrims can have a broader impact in efforts to build people's welfare and can build "peer networks" in community development activities. This paper is not an applicative study of a study but contains theoretical-academic exposures, which explain the efforts to develop Islamic society in congregation. In this article, it was explained the reason for the need for community development activities carried out in congregation, what strengths the pilgrims have and the stages of forming strong and independent jama'ah. Keywords: Manhaj Jamaah, Da'wah, Community Development.
\end{abstract}

Abstrak: Islam sebagai agama rahmatanlil'alamin bermakna bahwa Islam itu universal dan fleksibel terhadap semua aspek kehidupan makhluk, termasuk kehidupan umat manusia. Dakwah Islam menyentuh pembangunan sumber daya komunitas muslim dan masyarakat global dalam memanusiakan manusia, mencapai taraf hidup layak secara material dan immaterial (hasanah fid-dunya wal akhirat). Akan tetapi, ketersediaan potensi sumberdaya alam itu belum maksimal dimanfaatkan karena rendahnya kemampuan dan lemahnya etos kerja. Oleh karena itu, pembentukan manhaj jama'ah dalam kegiatan pengembangan dan pemberdayaan menjadi penting untuk dilaksanakan. Pengembangan yang dipusatkan pada jamaah dapat memberikan dampak yang lebih luas dalam upaya membangun kesejahteraan umat dan dapat membangun "jaringan sebaya" dalam kegiatan pengembangan masyarakat. Paper ini bukanlah kajian aplikatif dari sebuah penelitian melainkan berisi paparan teoritis-akademis, yang menjelaskan upaya pengembangan masyarakat Islam itu dilakukan secara berjamaah. Dalam artikel ini dijelaskan alasan perlunya kegiatan pengembangan masyarakat itu dilakukan secara 
86 Icol Dianto, Pembentukan Manhaj Jamaah Dalam Pengembangan Masyarakat Islam Jurnal At-Taghyir : Jurnal Dakwah dan Pengembangan Masyarakat Desa

Volume 1 Nomor 2 Juni 2019, h. 85-101

berjamaah, kekuatan apa yang dimiliki oleh jamaah dan tahapan membentuk jama'ah yang kuat dan mandiri.

Kata Kunci: Manhaj Jamaah, Dakwah, Pengembangan Masyarakat.

\section{A. Pendahuluan}

Isu sosial di Indonesia, tertuju pandangan kepada umat Islam karena umat yang paling dominan mendiami kepulauan nusantara ini beragama Islam. Terlepas dari kualitas keislaman masyarakat, banyak ditemukan bahwa pelaku patologis seperti; kemiskinan, kelaparan dan keterbelakangan, adalah mereka yang memiliki identitas agama Islam. Secara eksplisit, kondisi tersebut menggambarkan bahwa penganut Islam identik dengan patologis. Pada sisi lain, inti ajaran Islam itu malah memotivasi manusia untuk mengusahakan kebahagiaan hidup baik di dunia hingga akhirat kelak.

....maka di antara manusia ada orang yang berdoa, "Ya Tuhan kami, berilah kami (kebaikan) di dunia", dan tiadalah baginya bahagian (yang menyenangkan) di akhirat. Dan di antara mereka ada orang yang berdoa, "Ya Tuhan kami, berilah kami kebaikan di dunia dan kebaikan di akhirat dan peliharalah kami dari siksa neraka".

Ayat di atas memberikan semangat kepada manusia untuk meminta kebaikan dunia dan akhirat. Kebaikan di dunia bisa dalam bentuk kebahagiaan, ketenangan, dan terpenuhinya kebutuhan hidup baik lahir (materil, fisik) dan batin (immaterial, jiwa). Konsep agama yang demikian itu tetap saja menjadi kumpulan wahyu suci bagi pemeluknya jika tidak ditafsirkan dalam bentuk panduan praktis bagaimana mewujudkan kebaikan di dunia dan kebaikan di akhirat. Oleh karena itu, sudah seharusnya kegiatan dakwah diperbanyak, dampak diperluas, dan berorientasi pada perencanaan, proses dan hasil, dalam memperbaiki kondisi keumatan.

Selama ini, dakwah dipahami oleh masyarakat umum sebatas penyampaian informasi, usaha menginformasikan nilai-nilai Islam untuk diaplikasikan dalam kehidupan. Pemahaman ini telah memisahkan antara aktivitas dakwah dengan aktivitas lainnya di setiap dimensi kehidupan umat manusia, terutama komunitas muslim. Dakwah seharusnya meliputi multi dimensi karena materi pokok dakwah itu juga universal. Islam rahmatanlil'alamin itu bermakna Islam yang fleksibel terhadap semua aspek kehidupan makhluk, termasuk kehidupan umat manusia. Dakwah Islam menyentuh pembangunan sumber daya komunitas muslim dan global dalam

\footnotetext{
${ }^{1}$ Al-Quran In Word, 2003, QS. Al-Baqarah: 200-201
} 
87 Icol Dianto, Pembentukan Manhaj Jamaah Dalam Pengembangan Masyarakat Islam Jurnal At-Taghyir : Jurnal Dakwah dan Pengembangan Masyarakat Desa

Volume 1 Nomor 2 Juni 2019, h. 85-101

memanusiakan manusia, mencapai taraf hidup layak secara material dan immaterial yang dalam bahwa agama disebut sebagai hasanah fid-dunya wal akhirat. Dakwah Islam yang menjawab problematika umat dan diharapkan dapat meningkatkan kesejahteraan umat.

Islam dapat dijadikan sebagai modal dasar untuk mengembangkan masyarakat. ${ }^{2}$ Mohammad Quraish Shihab menulis bahwa cita-cita sosial Islam untuk menggapai kesejahteraan dunia dan akhirat merupakan kekuatan besar yang dimiliki umat. Banyak pakar saat ini memandang hanya zakat, sedekah dan bentuk sumbangan keuangan lainnya saja, padahal semua itu akan menjadi berarti jika cita-cita sosial Islam tersebut sudah tertanam dengan kuat pada umat.

Untuk mencapai kesejahteraan lahir, Islam tidak menjadikan zakat, sedekah, dan sebagainya sebagai jalan keluar utama. Cita-cita sosial Islam (kesejahteraan sosial yang diperjuangkan), bukan sekedar bantuan keuangan, apapun bentuknya, seperti yang dikenal dengan istilah kesejahteraan sosial dan jaminan sosial. Bantuan keuangan hanya merupakan satu dari sekian banyak bentuk bantuan yang dianjurkan oleh Islam. ${ }^{3}$

Islam mengajarkan agar manusia memperhatikan kesejahteraan generasi dewasa ini dan generasi yang akan datang. Agama mengecam umat yang telah mengabaikan kesejahteraan tersebut. Apalagi mereka umat yang saat itu mengetahui dengan sadar bahwa generasi yang akan mereka tinggalkan itu adalah kaum yang lemah (dhu'afa).

"dan apabila sewaktu pembagian itu hadir kerabat, anak yatim dan orang miskin, Maka berilah mereka dari harta itu (sekedarnya) dan ucapkanlah kepada mereka Perkataan yang baik. dan hendaklah takut kepada Allah orang-orang yang seandainya meninggalkan dibelakang mereka anak-anak yang lemah, yang mereka khawatir terhadap (kesejahteraan) mereka. oleh sebab itu hendaklah mereka bertakwa kepada Allah dan hendaklah mereka mengucapkan perkataan yang benar. ",

Sebenarnya, potensi yang dimiliki umat Islam sangat besar, baik potensi sumber daya manusia (SDA) maupun sumber daya alam (SDM). Sebut saja, potensi SDA, yang mana sepertiga penduduk dunia adalah umat Islam. Demikian juga dengan geografis yang dihuni oleh umat Islam menyimpan banyak energi dan barang tambang lainnya. Wilayah timur tengah yang tandus dipenuhi padang pasir, namun kaya dengan minyak.

\footnotetext{
${ }^{2}$ Icol Dianto, Peranan Dakwah dan Pengembangan Masyarakat Islam, Jurnal Hikmah, 12 (1), Juli 2018, hlm. 95

${ }^{3}$ Quraish Shihab, Membumikan Al-Quran, (Bandung, PT Mizan Pustaka, Cet. II, 2007), hlm. 378

${ }^{4}$ Al-Quran In Word, 2003, QS. An-Nisa: 8-9
} 
88 Icol Dianto, Pembentukan Manhaj Jamaah Dalam Pengembangan Masyarakat Islam Jurnal At-Taghyir : Jurnal Dakwah dan Pengembangan Masyarakat Desa

Volume 1 Nomor 2 Juni 2019, h. 85-101

Wilayah timur, seperti Indonesia, selain kaya dengan sumber daya energi, juga merupakan manifestasi surga di dunia, mengalir sungai-sungai dan dipenuhi oleh kebun buah-buahan. Akan tetapi, belum semua potensi itu yang digunakan umat Islam. Hal ini dikarenakan rendahnya kemampuan dan lemahnya etos kerja. Padahal, ajaran agama mendorong agar umat Islam berusaha sekuat tenaga. Tidak ada konsep hidup bermalasmalasan sehingga menimbulkan kemiskinan dan melahirkan generasi yang lemah. Apabila telah selesai satu pekerjaan maka beralihlah untuk memulai pekerjaan lainnya. ${ }^{5}$ Pepatahnya, bekerjalah Anda seakan-akan Anda hidup seribu tahun lagi dan beribadahlah Anda seakan-akan Anda mati esok pagi. Dari segi potensi kuantitas umat ini, belum adanya kesadaran untuk menjalin kesatuan dan persatuan, terutama sesama muslim. Ini juga bertentangan dengan konsep Islam. Umat Islam itu bersaudara, apakah itu persaudaraan keturunan, kekerabatan, daerah, dan apalagi persaudaraan agama.

Untuk membangkitkan potensi yang memang belum semuanya tergarap, step by step, kekuatan itu dicoba untuk dibangkitkan. Salah satu upaya yang selalu digencarkan masyarakat modern saat ini adalah dengan melakukan pemberdayaan. Kegiatan pemberdayaan yang dipusatkan pada kelompok dapat memberikan dampak yang lebih luas dalam upaya membangun kesejahteraan umat dan dapat membangun "jaringan sebaya" dalam kegiatan pengembangan masyarakat. Pada suatu gerakan yang besar dapat menghasilkan dampak yang luas.

\section{B. Pembahasan}

1. Definisi Manhaj

Definisi al-manhaj adalah jalan yang nyata dan terang. Allah berfirman, "untuk tiap-tiap umat di antara kamu, kami berikan syariat dan manhajâ (al-Maidah: 48), yaitu syariat dan jalan yang terang lagi jelas. Manhaj adalah metodologi menerima, mengalisis dan menerapkan pengetahuan. Jika dihubungkan dengan jamaah, maka manhaj merupakan metodologi menerima, mengalisis dan menerapkan pengetahuan berdasarkan kelompok. Syaikh Shalih al Fauzan mengatakan, "Manhaj itu lebih luas dari pada akidah. Ada manhaj dalam berakidah, berperilaku, berakhlak, bermuamalah dan dalam semua sisi kehidupan seorang muslim. Seluruh langkah yang ditempuh oleh

\footnotetext{
${ }^{5}$ Al-Quran In Word, 2003, Q.S. Al-Insyirah: 7-8
} 
89 Icol Dianto, Pembentukan Manhaj Jamaah Dalam Pengembangan Masyarakat Islam Jurnal At-Taghyir : Jurnal Dakwah dan Pengembangan Masyarakat Desa

Volume 1 Nomor 2 Juni 2019, h. 85-101

seorang muslim (dalam seluruh aspek kehidupan, pent) itu disebut dengan istilah manhaj.

2. Definisi Jamaah

Jamaah adalah term agama. Islam menyebutnya dengan jamaah, sedangkan jemaat merupakan istilah Kristen. Secara bahasa, jamaah berasal dari bahasa Arab yang memiliki arti, berkumpul. Misalnya, jamaah pasar berarti perkumpulan orang yang ada di pasar. Jamaah menurut istilah dapat diartikan sebagai pelaksanaan ibadah secara bersama-sama yang dipimpin oleh seorang imam. Misalnya jamaah shalat, jamaah haji, dll. Berkumpul (al-tajammu'), merupakan kenyataan penting untuk mengukuhkan agama Islam di dalam kehidupan umat. ${ }^{6}$ Bahkan, Islam tidak mungkin berdiri kokoh tanpa adanya jamaah yang senantiasa bersatu padu.

Kata jamaah semata-mata menunjukan suatu kelompok kecil masyarakat tetapi lebih luas dari keluarga yang hidup bersama menyelesaikan persoalan hidup mereka secara bersama baik dalam bidang ubudiah, maupun bidang kehidupan lainnya, seperti ekonomi, kesehatan, budaya dan politik. ${ }^{7}$ Apa yang disebut jamaah dalam konsep ini, lebih sesuai dengan kelompok dalam ilmu sosiologi. Bedanya terletak pada ikatan kebersamaan. Ikatan antar anggota jamaah tidak hanya ditentukan oleh faktor-faktor ekonomi, sosial, dan budaya. Akan tetapi, jamaah lebih menekankan pada ikatan persaudaraan imani (Islam) yang isinya terkait dengan akidah, syariah dan muamalah termasuk faktor-faktor ekonomi, sosial, dan budaya. Tujuan jamaah adalah mewadahi setiap pribadi, menyelesaikan berbagai persoalan hidup bersosial, dan didorong dengan semangat mengamalkan ajaran Islam.

Walaupun banyak aktivitas jamaah menyangkut aktivitas ekonomi dan kesehatan, tetapi didorong semangat yang tercantum dalam pokok ajaran Islam, ta'awun, tolong-menolong dalam berbagai masalah untuk mewujudkan kebaikan hidup. Jamaah adalah wadah bagi umat Islam dalam menjalankan ibadah. Di dalam jamaah, terdapat imam atau amir atau sultan, dan ada rukyah atau makmum. Sama halnya dalam

6 Amahzun, Muhammad Manhajun Nabiyy Fid-Da'wah, seri terjemah oleh Anis Maftukhin dan Nandang Burhanuddin, Manhaj Dakwah Rasulullah, (Jakarta; Qisthi Press, 2005), hlm. 165.

${ }^{7}$ Mulkhan, Abdul Munir. Ideologisasi Gerakan Dakwah: Episode Kehidupan M Natsir dan Azhar Basyir, (Yogyakarta, Sipress, 1996), hlm. 214. 
90 Icol Dianto, Pembentukan Manhaj Jamaah Dalam Pengembangan Masyarakat Islam Jurnal At-Taghyir : Jurnal Dakwah dan Pengembangan Masyarakat Desa

Volume 1 Nomor 2 Juni 2019, h. 85-101

shalat, ada imam ada makmum. Walaupun ribuan umat salat di masjid bersama, tapi tanpa ada imam, tidak bisa dikatakan salat berjamaah. Akan tetapi, walau hanya tiga orang, kalau salah satu maju menjadi imam, maka itu salat berjama'ah.

3. Pembentukan Manhaj Jamaah

a. Kecenderungan Manusia Terhadap Manhaj Jamaah

Manusia adalah makhluk sosial yang tidak bisa hidup sendirian. Manusia pertama (Nabi Adam as) merasa kesepian di surga dan berdoa supaya diberi pendamping dan teman hidup. Dalam al-Quran dijelaskan bahwa manusia diciptakan berpasang-pasangan. ${ }^{8}$ Pada tahap ini, terbentuklah institusi sosial pertama, yaitu keluarga. Keluarga merupakan bayangan mikro dari organisasi terbesar. Pada institusi keluarga ini ada pemimpin dan rakyat, ada peraturan dan hukuman, ada hak dan kewajiban, ada tugas dan tanggung jawab. Unsur-unsur Negara bahkan dimiliki oleh keluarga sesuai dengan konteksnya sebagai institusi sosial terkecil dalam kehidupan bermasyarakat.

Keluarga berhimpun dengan keluarga lainnya maka lahirlah organisasi sosial yang lebih besar, sebuah kehidupan bersama (jamaah). Perintah agama memberikan mandat untuk umatan wasathan ${ }^{9}$ ini, untuk menjalin hubungan sesama manusia. Allah menciptakan manusia dengan perbedaan suku dan bangsa ${ }^{10}$ namun memiliki tujuan persatuan dalam perbedaan. Membangun persatuan dengan jalan saling kenal-mengenal, memahami dan menghargai perbedaan yang ada, sehingga manusia itu kembali kepada fitrahnya yaitu umat yang satu. ${ }^{11}$

Khusus umat yang telah disatukan oleh dasar agama Islam, maka setiap pemeluknya itu bagaikan satu bangunan yang saling menguatkan, membantu dan tolong-menolong untuk menjalankan misi kehidupan dunia, yaitu menjadi manusia yang fitrah dalam menempuh sirath al-mustaqim, mengabdikan diri dengan menyembah dan beribadah hanya kepada Allah, dan menjalankan amanah sebagai khalifah Allah di muka bumi ini. Singkatnya, setiap individu dalam Islam mesti bahu-membahu mencapai kesenangan, kebahagiaan, kesuksesan dan kesejahteraan dunia dan akhirat. Mengenai

${ }^{8}$ Al-Quran In Word, 2003, QS. Adz-Dzariyat: 49

${ }^{9}$ Al-Quran in Word, 2003, QS. Al-Baqarah: 143

${ }_{11}^{10}$ Al-Quran in Word, 2003, QS. Al-Hujurat: 13

${ }^{11}$ Al-Quran in Word, 2003, QS. Al-Anbiya: 92 dan QS. Al-Baqarah: 213 
91 Icol Dianto, Pembentukan Manhaj Jamaah Dalam Pengembangan Masyarakat Islam Jurnal At-Taghyir : Jurnal Dakwah dan Pengembangan Masyarakat Desa

Volume 1 Nomor 2 Juni 2019, h. 85-101

kebersamaan umat Islam di akhirat kelak, Nabi Muhammad Saw mewasiatkan agar umatnya selalu berpegang dengan jamaah karena kalau sendirian maka setan akan datang menggodanya sehingga umat tidak masuk surga melainkan tersesat ke neraka. ${ }^{12}$ Nabi Muhammad Saw juga menerangkan bahwa kelak seseorang akan mencari teman dan sahabatnya yang satu kelompok/jamaah sampai mereka menjemput dan menyelamatkan sahabatnya yang berada di neraka. ${ }^{13}$

Berdasarkan uraian di atas dapat dipahami bahwa sesungguhnya setiap manusia memiliki kecenderungan dalam dirinya untuk hidup bersama (berjamaah) dengan pihak lain. Dorongan-dorongan tersebut dipertegas lagi dalam konsep ibadah dalam Islam. Salah satunya ibadah sholat. Nabi Muhammad Saw menegaskan bahwa sholat yang dilakukan secara berjamaah memiliki keunggulan pahala sampai dua puluh tujuh derajat (tingkatan) dibandingkan dengan sholat yang dilakukan secara sendiri-sendiri.

b. Kajian Jamaah dalam Ilmu Sosial

Dalam kajian Sosiologi, jamaah mendekati pengertiannya dengan kelompok. David $\mathrm{Cs}^{14}$ memberikan definisi kelompok adalah agregat sosial di mana anggotaanggota yang saling tergantung, setidak-tidaknya memiliki potensi untuk berinteraksi satu sama lainnya. Ada batasan-batasan suatu kerumunan orang dikatakan kelompok jika ada peran sosial, kekompakan, berbicara, dan kepemimpinan, serta hubungan komunikasi. Batasan-batasan ini dimiliki oleh sistem jamaah yang dipimpin oleh seorang imam/pemimpin yang berfungsi sebagai pemandu. Akan tetapi, dalam makalah ini lebih mengarahkan kepada metode pembentukan jamaah, bukan proses terbentuknya kelompok.

Pada tahapan ini juga, menurut Sigmund Freud mengungkapkan sebuah teori jika individu berkumpul membentuk massa, maka mereka akan meninggalkan pola pikir

\footnotetext{
${ }^{12}$ Hadis Nabi Muhammad Saw yang diriwatkan oleh At-Tirmidzi, Ahmad dan Al-Hakim dalam situs https://minanews.net/umat-yang-satu/ diakses pada 3 April 2019, pukul 14.47 WIB.

${ }_{13}$ "Wahai Tuhan Kami, mereka itu (yang tinggal di Neraka) pernah berpuasa bersama kami, shalat dan juga haji. Dijawab (Allah), "Keluarkanlah (dari neraka) orang-orang yang kalian kenal." Hadis ini diriwayatkan oleh Imam Muslim No.183. dikutip dari situs https://muslimafiyah.com/para-sahabat-saling-memberi-syafaat-di-hari-kiamat.html diakses pada 3 April 2019 pukul 14.58 WIB.

${ }^{14}$ David O. Sears dan Jonathan L. Freedman dan L. Anne Pepleu. Psikologi Sosial, (PT Gelora Aksara Pratama, 1985), hlm. 107.
} 
92 Icol Dianto, Pembentukan Manhaj Jamaah Dalam Pengembangan Masyarakat Islam Jurnal At-Taghyir : Jurnal Dakwah dan Pengembangan Masyarakat Desa

Volume 1 Nomor 2 Juni 2019, h. 85-101

masing-masing dan beralih ke pikiran kolektif yang ada dalam kelompok tersebut ${ }^{15}$ Dalam kerangka berpikir untuk mengembangkan konsep perilaku kelompok yang membentuk kualitas sinergi, dalam penulisan disertasi Sulasmi (2003) dibedakan tiga dimensi perilaku sebagai berikut, yaitu: ${ }^{16}$

a. Perilaku Kerjasama yang diartikan sebagai perilaku anggota kelompok yang mengutamakan kebersamaan dalam berbagai aktifitas kerja, dengan cara saling membantu, mendorong, dan berbagi informasi dalam mengatasi permasalahan bersama. Ini adalah perilaku yang didukung oleh semangat kerjasama (co-operative spirit) yang tinggi dari para anggota kelompok.

b. Perilaku Belajar Inovatif yang diartikan sebagai perilaku anggota kelompok untuk selalu belajar dari pengalaman sebelumnya, mempertanyakan sesuatu yang sudah mapan, dan tidak henti mencari gagasan-gagasan baru untuk memenuhi tantangan lingkungan. Kelompok yang berperilaku belajar inovatif, didukung oleh para anggotanya yang mempunyai semangat belajar inovatif (innovative spirit).

c. Intensitas Kerja yaitu keaktifan anggota kelompok yang sangat tinggi dan tuntas dalam menjalankan tugasnya. Intensitas kerja kelompok didukung oleh para anggotanya yang bermotivasi kerja yang tinggi (work spirit).

Senge dalam Siti Sulasmi ${ }^{17}$ menjelaskan bahwa semangat berkelompok ini menjadi produktif, bila anggota kelompok bersifat kritikal, karena mereka selalu mencari hal-hal yang baru dan inovatif. Bahkan, semangat berkelompok ini akan makin meningkat, bila anggota kelompok bekerja keras, tuntas, dan berorientasi pada kualitas, yang didukung oleh infrastruktur organisasi yang inovatif (Senge 1996). Dipandang dari proses perkembangan yang selalu terjadi pada sebuah kelompok, maka kemampuan untuk bekerjasama, berperilaku belajar inovatif, mencerminkan kelompok yang berhasil berkembang mencapai tingkat kematangannya. Menurut teori perkembangan kelompok, kelompok yang berhasil mencapai tingkat kematangannya akan mampu pula menghasilkan kualitas kerja yang sinergistik. Menurut Kast dan Rosenzweig (1981),

\footnotetext{
${ }^{15}$ Kartika Sunu Wati, Modal Dalam Praktik Sosial Arisan Sosialita, Jurnal Idea Societa, 2 (5), Oktober 2015, hlm. 2

16 Siti Sulasmi, Peran Variabel Perilaku Belajar Inovatif, Intensitas Kerjasama Kelompok, Kebersamaan Visi dan Rasa Saling Percaya dalam Membentuk Kualitas Sinergi, Ekuitas, 13 (2), Juni 2009, hlm. 222

${ }_{17}^{17}$ Siti Sulasmi, ibid, hlm. 222
} 
93 Icol Dianto, Pembentukan Manhaj Jamaah Dalam Pengembangan Masyarakat Islam Jurnal At-Taghyir : Jurnal Dakwah dan Pengembangan Masyarakat Desa

Volume 1 Nomor 2 Juni 2019, h. 85-101

kelompok yang berhasil mencapai kematangannya berhasil pula mengatasi hambatannya. Dalam penelitian yang dilakukan oleh Sulasmi (2003) ini, konsep kualitas sinergi yang dikembangkan terbentuk dari perilaku kerjasama anggotanya, perilaku belajar inovatif, dan intensitas kerja. Kualitas sinergi yang dihasilkan adalah hasil kerja dari sebuah kelompok yang mampu mencapai kematangannya, dalam pengertian berhasil mengorganisasikan pekerjaan melalui hubungan kerjasama yang baik di antara anggotanya. Dalam dimensi tugas, kematangan tersebut ditunjukkan oleh kemampuan anggota kelompok untuk memadukan suatu gagasan yang komplementer menjadi gagasan baru untuk menanggulangi masalah yang dihadapi maupun mengantisipasi masalah di masa mendatang.

\section{Gerakan Manhaj Jamaah Dalam Dakwah}

Statemen Hamka ${ }^{18}$ untuk menghidupkan dakwah, sudah sepatutnya umat muslimin teguh menegakan jamaahnya dengan meramaikan masjid. Konsekuensi dari ide gerakan dakwah ini menjadikan masjid sebagai basis aktivitas dakwah. Dakwah jamaah adalah suatu model kegiatan dakwah yang menjadikan kehidupan jamaah sebagai sarana dakwah dan wadah untuk mencapai tujuan bersama. Dengan kata lain, dakwah jamaah ialah upaya mengembangkan dan membina kehidupan jamaah menjadi kehidupan yang lebih Islami. ${ }^{19}$ Membangun kesadaran umat untuk berjamaah dalam menghadapi problematika kehidupan bila diamati dari perspektif pemenuhan kebutuhan dasar manusia, sangat penting untuk dilakukan. Kelompok yang didasari oleh kekokohan imani akan memiliki kesadaran yang tinggi, yang dengan modal itu dapat bertahan dan selalu kompak untuk membangun kekuatan ekonomi, sosial, politik dan budaya. Dalam QS. Al-'Ashr: 1-4 dan QS. Al-Balad: 15-17, disebutkan bahwa konsekuensi dari keimanan adalah amal sholeh, dan terus istiqomah dalam menjalankan keimanan itu. Sesama muslim hendaknya senantiasa saling mengingatkan saudarasaudaranya dalam hal kebenaran, penuh kesabaran, dan diliputi rasa kasih sayang. Hanya dengan itulah kemantapan kesadaran dan perasaan senasib sepenanggungan dapat dibangun.

\footnotetext{
${ }^{18}$ Hamka, Prinsip dan Kebijaksanaan Dakwah Islam, (Jakarta; PT Pustaka Panjimas, 1984), hlm. 216

${ }^{19}$ Mulkhan, Abdul Munir. Ideologisasi Gerakan Dakwah: Episode Kehidupan M Natsir dan Azhar Basyir, (Yogyakarta, Sipress, 1996), hlm. 215.
} 
94 Icol Dianto, Pembentukan Manhaj Jamaah Dalam Pengembangan Masyarakat Islam Jurnal At-Taghyir : Jurnal Dakwah dan Pengembangan Masyarakat Desa

Volume 1 Nomor 2 Juni 2019, h. 85-101

Dakwah bukan sekedar proses yang memperkenalkan manusia dengan Tuhannya. Akan tetapi, dakwah merupakan proses transformasi atau perubahan sosial. Nabi Muhammad Saw. pernah mengutus Muadz bin Jabal ke Negeri Yaman. Yang pertama diajarkan adalah mengenal Allah. Mengenal Allah merupakan ilmu tentang tauhid dan keimanan. Kemudian diajarkan kepada umat persoalan ibadah fardhu, dan ibadah yang memiliki nilai-nilai sosial (amal shaleh). Dalam transformasi sosial di era modernitas, ada tujuh penyakit yang dapat merusak tatanan kehidupan sosial yang baik. Machendrawati dan Agus $^{20}$ mengutip pendapat Jalaluddin Rachmat yang dikutipnya dari Lyman, the seven deadly sins alias tujuh dosa maut, yaitu ketidakpedulian, nafsu, angkara murka, kesombongan, iri hati, lahap dan kerakusan. Tujuh hal ini bagian dari problem yang dihadapi masyarakat yang sedang bergerak menuju kearah modern. Ini pula yang harus diwaspadai oleh para dai dan siapa saja yang concern terhadap berbagai persoalan yang dihadapi masyarakat.

Dilihat dari kaca mata kultural-psikologis, persoalan yang dikhawatirkan merusak visi dan misi perubahan, memerlukan penanganan yang serius. Itu berarti agama harus diturunkan sebagai wacana budaya yang diyakini bisa menjawab berbagai tantangan budaya kontemporer. Maksudnya, bukan menjadikan agama hanya sebuah kebudayaan melainkan realisasi nilai-nilai agama dapat mewarnai kebudayaan umat. Kajian ini sangat perlu dipahami, karena pembentukan jamaah pada hakikatnya mewujudkan khairul ummah di tengah komunitas global. Tanpa kesediaan menjadikan agama sebagai wacana budaya, menurut Mulkhan, ${ }^{21}$ gerakan dakwah ataupun gerakan pengembangan masyarakat akan mengalami kesulitan untuk secara sungguh-sungguh peduli terhadap penderitaan dan kemiskinan. Akan tetapi, dengan strategi pengembangan agama sebagai wacana budaya dan seni, maka dakwah Islam dan gerakan pengembangan masyarakat mungkin bisa menempatkan diri sebagai pemeran strategis bagi sebuah Indonesia yang lebih baik.

Konsep dan strategi dakwah harus diarahkan pada pemecahan berbagai persoalan yang dihadapi masyarakat di lapangan. Dakwah sebagai pemecahan masalah diharapakan akan menghasilkan tiga kondisi berikut, tumbuhnya kepercayaan dan

\footnotetext{
${ }^{20}$ Machendrawati dan Agus, Pengembangan Masyarakat Islam...,hlm. 34 hlm. 3

${ }^{21}$ Abdul Munir Mulkhan, Ideologisasi Gerakan Dakwah, (Yogyakarta, Sipress, 1999),
} 
95 Icol Dianto, Pembentukan Manhaj Jamaah Dalam Pengembangan Masyarakat Islam Jurnal At-Taghyir : Jurnal Dakwah dan Pengembangan Masyarakat Desa

Volume 1 Nomor 2 Juni 2019, h. 85-101

kemandirian umat serta masyarakat sehingga berkembang sikap optimis, tumbuhnya kepercayaan terhadap kegiatan dakwah guna mencapai tujuan kehidupan yang lebih baik, dan berkembangnya suatu kondisi sosio-ekonomi-budaya-politik-iptek sebagai landasan peningkatan kualitas hidup atau peningkatan kualitas sumber daya umat. Dengan demikian, dakwah sebagai pemecahan merupakan upaya yang demokratis bagi pengembangan dan peningkatan kualitas hidup sebagai bagian pengembangan masyarakat dalam menyelesaikan berbagai persoalan kehidupan objektif.

Melalui dakwah, pemecahan persoalan dan pengembangan masyarakat maka kelompok masyakat yang kecilpun dapat dikembangkan menjadi komunitas sosial yang mempunyai kemampuan internal yang bekembang mandiri dalam menyelesaikan persoalan yang dihadapi. Dengan demikian, pengembangan kemampuan dan kualitas sumber daya umat dalam lingkup kecil, seperti keluarga atau jamaah, harus mendapatkan perhatian seluruh lembaga formal dakwah Islam, dan siapapun yang terencana dan sistematis.

5. Manhaj Jamaah: Model Alternatif Dalam Pengembangan Masyarakat

Pada awal Islam berkembang, Rasulullah menyeru secara diam-diam kepada kerabat dekat. Yang pertama diajarkan rasul adalah pengetahuan tentang aqidah atau keimanan. Setelah keimanan pengikut beliau diperkirakan tangguh, barulah beliau mengajarkan ibadah. Ini sebuah gambaran sejarah bagi generasi saat ini, bahwa untuk membentuk jamaah harus dimulai dengan memberikan pengetahuan tentang aqidah dan keimanan. Amahzun ${ }^{22}$ mengutip firman Allah QS. al-'Ashr: 1-3.

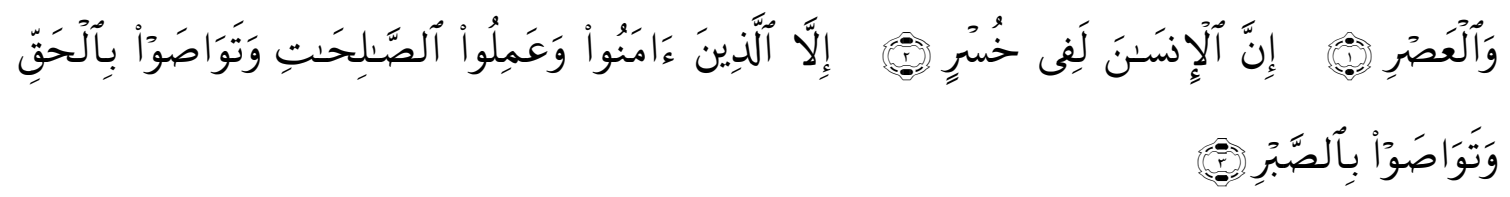

"Demi masa. Sesungguhnya manusia itu benar-benar dalam kerugian, kecuali orangorang yang beriman dan mengerjakan amal saleh dan nasehat menasehati supaya mentaati kebenaran dan nasehat menasehati supaya menetapi kesabaran”.

Menurut Amahzun, perintah menyampaikan risalah Tuhan, dari Allah ke Malaikat Jibril, diterima oleh Rasulullah SAW, lalu diteruskan oleh sahabat, tabi'in, tabi'it-tabi'in, ulama dan umat, tidak akan dapat berjalan dengan baik kalau tidak

${ }^{22}$ Amahzun, Muhammad Manhajun Nabiyy Fid-Da'wah..., hlm. 165-166. 
96 Icol Dianto, Pembentukan Manhaj Jamaah Dalam Pengembangan Masyarakat Islam Jurnal At-Taghyir : Jurnal Dakwah dan Pengembangan Masyarakat Desa

Volume 1 Nomor 2 Juni 2019, h. 85-101

didukung dengan kesadaran berjamaah, segolongan umat yang beriman lagi beramal shaleh, untuk nasehat-menasehati dalam kebenaran dan nasehat-menasehati dalam kesabaran.Munculnya jamaah dikarenakan beragam alasan sesuai kebutuhan masyarakat. Adakalanya mereka berkumpul karena alasan keagamaan, sosial, dan organisasi. Jamaah merupakan kelompok yang terbentuk karena kebutuhan yang bersifat keagamaan. Dalam perspektif pemberdayaan, jamaah akan terbentuk apabila kelompok tersebut menerima pengetahuan, menerima bujukan, putusan, mengimplementasikan, dan pemastian.

Menerima pengetahuan maksudnya, sekumpulan orang yang akan dibina disadarkan akan potensi-potensi yang ada. Potensi jamaah adalah kebersamaan dalam menyelesaikan persoalan kehidupan, seperti problema kehidupan sosial, agama, ekonomi, politik, dan budaya. Pada tahap ini, pemberdaya berupaya menumbuhkan kesadaran berpikir tentang potensi jamaah dalam menjaga kelestarian agama, sosial dan budaya, serta keuntungan-keuntungan yang mungkin dapat diperoleh melalui berjamaah. Menerima bujukan, maksudnya pemberdaya harus sabar mengajak dan menasehati calon jamaah agar segera berbuat dan mengikuti saran-sarannya. Pada tahap ini diupayakan agar jamaah dengan kesadaran pribadinya terdorong untuk melakukan action. Inilah yang harus diputuskan oleh sekelompok orang, agar segera buat bukan sekedar berpendapat. Tahap ini disebut juga tahapan menumbuhkan kesadaran bertindak bagi masyarakat. Tahap putusan yang dimaksud adalah tahap masyarakat untuk segera mengambil kesimpulan, memulai aksi atau tidak. Beberapa tahap sudah dilewati, penumbuhan kesadaran untuk merubah pendapat (kesadaran berpikir), persuasif atau membujuk untuk ber-action, dan kini saatnya untuk memutuskan segera ber-action.

Penjelasan-penjelasan yang menerpa masyarakat, semua diproses dalam otak, dan melahirkan gerak atau tidak, untuk mengambil tindakan yang tepat. Jika pesanpesan pada tahap sebelumnya berhasil menyentuh kesadaran masyarakat, maka kemungkinan besar pesan itu akan diimplementasikan dalam bentuk tindakan nyata. Amahzun $^{23}$ menjelaskan bahwa ada beberapa Manhaj Rasulullah dalam mengembangkan komunitas Islam di Mekah. Manhaj tersebut menyentuh bidang pengetahuan, pembinaan, perencanaan, dan sistem pelaksanaan dakwah. Adapun bidang

${ }^{23}$ Amahzun, Muhammad Manhajun Nabiyy Fid-Da'wah..., hlm. xxi-xxiv. 
97 Icol Dianto, Pembentukan Manhaj Jamaah Dalam Pengembangan Masyarakat Islam Jurnal At-Taghyir : Jurnal Dakwah dan Pengembangan Masyarakat Desa

Volume 1 Nomor 2 Juni 2019, h. 85-101

pengetahuan meliputi pengetahuan tentang Allah, sunnah-sunnah Rabbaniyah, dan menjelaskan tujuan hijrah. Bidang pembinaan dilakukan melalui kejadian-kejadian (peristiwa yang dihadapi kaum muslimin), pembinaan melalui amalan hati, pembinaan melalui akhlak, pembinaan yang komprehensif dan integral, dan teguh pada prinsip dan anti kompromi. Bidang perencanaan meliputi perencanaan permulaan dakwah tertutup, fase kedua dakwah terbuka, mencari dukungan dan mengetahui kondisi sosial, dan psikologis lingkungan dakwah. terakhir, bidang sistem pelaksanaan dakwah, baik dakwah sirriyah dalam jamaah yang tertutup, maupun pembinaan individu dalam ruang lingkup jamaah yang lebih besar.

Penjelasan Amahzun di atas mengarah pembicaraan pada manhaj dakwah Islam dalam pembentukan umat, dengan menggunakan kerangka berfikir kemanajemenan. Tahapan yang diberikan Rasulullah dalam membentuk umat Islam, dapat diaplikasikan ke konsep yang lebih kecil dan konsep yang lebih besar. Konsep yang lebih kecil yang dimaksud adalah pembentukan jamaah, sedangkan konsep yang lebih besar adalah pembentukan dan pembinaan masyarakat global, seperti peristiwa yang terjadi di masa kejayaan Islam, yang mana sepertiga dunia memeluk ad-dien al-Islam. Machendrawati dan Agus $^{24}$ memberikan rujukan kepada action yang dilakukan oleh Rasulullah Saw., dalam membina umat Islam. Ada tiga tahapan yang harus dibangun, tahapan takwin, tanzim, dan taudi'. Tahap pertama, menginternalisasikan nilai-nilai Islam dalam kehidupan masyarakat, kemudian mengekspresikan dalam ghirah dan sikap membela keimanan dari tekanan struktural (al-mala al-mutrafin) kaum penindas. Pada tahap ini, rasul melaksanakan dakwah untuk pembebasan. Menurut Amrullah Ahmad ${ }^{25}$ pada tahap takwin, fundamen sosial Islam dalam bentuk akidah, ukhuwah Islamiyah, ta'awwun, dan shalat sudah dapat diterapkan kepada masyarakat. Tauhid menjadi instrument sosiologis dalam mempersatukan para sahabat dan masyarakat muslim.

Kedua, tahap tanzim terfokus program pada pembinaan dan penataan masyarakat. Pada fase ini, internalisasi dan eksternalisasi Islam muncul dalam bentuk

${ }^{24}$ Machendrawati dan Agus, Pengembangan Masyarakat Islam: Dari Ideology, Strategi, Sampai Tradisi, (Bandung; PT Remaja Rosdakarya, 2001), hlm. 31-32.

${ }^{25}$ Ahmad, Amrullah. Strategi Dakwah Islam di Tengah Era Reformasi Menuju Indonesia Baru dalam Memasuki Abad ke-21. Makalah pada sarasehan nasional: "Menggagas Strategi Dakwah Menuju Indonesia Baru." (SMF Dakwah IAIN Sunan Gunung Djati, Bandung, 21 April 1999), hlm. 67 
98 Icol Dianto, Pembentukan Manhaj Jamaah Dalam Pengembangan Masyarakat Islam Jurnal At-Taghyir : Jurnal Dakwah dan Pengembangan Masyarakat Desa

Volume 1 Nomor 2 Juni 2019, h. 85-101

institusional Islam secara komprehensif dalam realitas sosial. Misalnya, peristiwa hijrah nabi dalam perspektif dakwah dilakukan ketika tekanan kultural, struktural, dan militer yang sangat mencekam sehingga jika tidak hijrah, bisa terjadi involusi kelembagaan dan menjadi lumpuh. Masyarakat yang sudah terkungkung dalam situasi sosio-kultural yang tidak mendukung, zalim dan merugikan karena diikat oleh tata nilai merendahkan sebagian golongan. Dengan berhijrah, masyarakat diajak meninggalkan kungkungan alam ini, menuju pandangan yang luas dan menyeluruh yang dapat menghilangkan kejumudan dan kemerosotan sosial, sehingga masyarakat yang jumud menjadi dinamis.

Pada tahap ini, modal sosial umat sudah terjalin dengan baik. Modal sosial juga merupakan salah satu modal yang memiliki peran besar dalam membentuk kehidupan seseorang, koneksi atau relasi sosial yang memungkinkan seseorang dapat memenuhi kepentingannya sendiri. Modal sosial datang dari keanggotaan kelompok-kelompok tertentu dan jaringan sosial. Modal sosial juga dapat mempengaruhi kekuasaan dan keuntungan ekonomi dan modal budaya. Seberapa besar modal sosial yang dimiliki oleh seorang agen tergantung pada seberapa besar jaringan koneksi yang dapat secara efektif memobilisasi modal-modal lainnya. ${ }^{26}$ Ketiga, tahapan taudi' adalah keterlepasan dan kemandirian. Pada tahap ini, jamaah telah siap menjadi masyarakat mandiri, terutama secara manajerial. Bila ketiga tahap ini telah dijalankan, bolehlah berharap akan munculnya suatu masyarakat Islam yang memiliki kualitas yang siap dipertandingkan dalam kelompok-kelompok masyarakat lain. Istilah kata Komunitas berasal dari bahasa latin communitas $^{27}$ yang berarti "kesamaan", kemudian dapat diturunkan dari communis yang berarti sama, publik, dibagi oleh semua atau banyak. Menurut Kertajaya Hermawan (2008: 32), komunitas adalah sekelompok orang yang saling peduli satu sama lain lebih dari yang seharusnya, dimana dalam sebuah komunitas terjadi relasi pribadi yang erat antar para anggota komunitas tersebut karena adanya kesamaan interest atau values. Kekuatan pengikat suatu komunitas, terutama, adalah kepentingan bersama dalam memenuhi kebutuhan kehidupan sosialnya yang biasanya, didasarkan atas kesamaan latar belakang budaya, ideologi, sosial-ekonomi. Di samping itu secara

\footnotetext{
${ }^{26}$ Kartika Sunu Wati, Modal Dalam Praktik Sosial Arisan Sosialita, Jurnal Idea Societa, 2 (5), Oktober 2015, hlm. 18

${ }_{27}$ Tika Wulandari, Pola Komunikasi Komunitas Kaskus Regional Riau Raya dalam Membentuk Kohesivitas Kelompok, Universitas Riau, 2014, hlm. 6. http://jom.unri.ac.id diakses pada Selasa, 5 Maret 2019.
} 
99 Icol Dianto, Pembentukan Manhaj Jamaah Dalam Pengembangan Masyarakat Islam Jurnal At-Taghyir : Jurnal Dakwah dan Pengembangan Masyarakat Desa

Volume 1 Nomor 2 Juni 2019, h. 85-101

fisik suatu komunitas biasanya diikat oleh batas lokasi atau wilayah geografis. Masingmasing komunitas, karenanya akan memiliki cara dan mekanisme yang berbeda dalam menanggapi dan menyikapi keterbatasan yang dihadapainya serta mengembangkan kemampuan kelompoknya.

6. Langkah-langkah membentuk Manhaj Jamaah

Kelompok adalah sekumpulan orang yang memiliki hubungan intensif, terdiri dari dua, tiga atau lebih, disatukan oleh tujuan yang sama, diikat oleh aturan-aturan tertentu, serta memiliki atribut/identitas yang sama. Hubungan yang intensif ditandai dengan sirkulasi tatap muka yang intensif sehingga dapat menimbulkan sentimentsentimen kelompok dan kerinduan di antara mereka. Adler dan Rodman dalam Sendjaja sebagaimana dikutip Bungin $^{28}$ menyebutkan bahwa ada empat elemen dalam pembentukan kelompok, yaitu interaksi, waktu, ukuran dan tujuan.

a. Interaksi

Interaksi ditandai dengan adanya kontak sosial dan komunikasi. Manhaj Jamaah sebagai wadah untuk mengintensifikasikan kontak sosial, berdialog, diskusi, dan bekerja sama. Intensitas berbaur, berdialog dan diskusi di antara anggota jamaah dapat mempererat hubungan. Dalam dimensi hubungan, kematangan itu ditunjukkan dari hubungan kerjasama yang saling menguntungkan (mutuality) dan saling ketergantungan (interdependence) dalam penyelesaian tugas mereka. Dengan demikian kualitas sinergi akan terwujud, bila kelompok sudah mencapai tingkat kebersamaan dan saling ketergantungan. Kondisi itu ditandai oleh sentimentalitas yang muncul di kalangan anggotanya, dalam bentuk saling pengertian, saling memahami, sehingga terwujud hubungan kerjasama yang saling menguntungkan. Anggota kelompok mencapai tingkat keyakinan bahwa hanya dengan saling tergantung dan bekerjasama, hal-hal yang rumit dapat diatasi bersama.

b. Waktu

Sekumpulan orang yang berinteraksi dalam waktu yang singkat tidak dapat dikatakan kelompok. Kelompok mempersyaratkan adanya interaksi dalam kurun waktu yang panjang, sehingga interaksi mereka melahirkan tindakan-tindakan yang khas,

${ }^{28}$ Bungin, Sosiologi Komunikasi: Teori, Paradigma, dan Diskursus Teknologi Komunikasi di Masyarakat, (Jakarta: Kencana, 2006), hlm. 268 
100 Icol Dianto, Pembentukan Manhaj Jamaah Dalam Pengembangan Masyarakat Islam Jurnal At-Taghyir : Jurnal Dakwah dan Pengembangan Masyarakat Desa

Volume 1 Nomor 2 Juni 2019, h. 85-101

menggambarkan ciri dan karakteristik yang dapat membedakannya dengan kerumunan orang yang hanya interaksi singkat dan bersifat sementara.

c. Ukuran

Meski tidak ada aturan baku yang dapat dijadikan batasan dalam menetapkan jumlah kelompok, namun yang dikatakan kelompok itu pasti sekumpulan orang, minimal dua orang. Para ahli memiliki kecenderungan untuk membagi kelompok itu menjadi tiga bagian, yaitu kelompok kecil, sedang dan besar. Kelompok kecil beranggota 2-15 orang, kelompok sedang beranggotakan 15-30 orang dan kelompok besar beranggotakan lebih dari 30 orang.

d. Tujuan

Keanggotaan dalam suatu kelompok akan membantu individu-individu yang bergabung pada kelompok tersebut, untuk dapat mewujudkan satu atau lebih tujuannya. Pada kelompok bertemunya dua tujuan yaitu tujuan-tujuan individu dan tujuan-tujuan kelompok. Tujuan-tujuan individu harus sejalan dengan tujuan-tujuan kelompok dan tujuan-tujuan kelompok haruslah menjamin ketercapaian tujuan individu.

\section{Penutup}

Artikel ini dapat memberikan kesimpulan bahwa manhaj pembentukan jamaah, maksudnya adalah cara-cara untuk membentuk jamaah. Ada beberapa tahapan dalam pembentukan jamaah, menerima pengetahuan, menerima bujukan, putusan, mengimplementasikan, dan kepastian. Selain itu, ada tiga tahapan untuk membentuk jamaah umat, takwin, tanzim, dan tuadi'. Pentingnya dipelajari manhaj pembentukan jamaah adalah untuk mengaktifkan kembali sistem dakwah rasulullah dalam upaya pengembangan komunitas Islam yang berkualitas agama, sosial, budaya, dan ekonomi. Aktualisasi nilai-nilai Islam melalui dakwah jamaah perspektif pemberdayaan masyarakat Islam. Mempelajari manhaj pembentukan jamaah diharapkan munculnya gerakan dakwah jamaah yang tangguh, step by step, menuju pembangunan komunitas Islam yang berkualitas yang mampu bersaing di era globalisasi.

Daftar Kepustakaan

Al-Quran in Word, 2003 
101 Icol Dianto, Pembentukan Manhaj Jamaah Dalam Pengembangan Masyarakat Islam Jurnal At-Taghyir : Jurnal Dakwah dan Pengembangan Masyarakat Desa

Volume 1 Nomor 2 Juni 2019, h. 85-101

Amahzun, Muhammad Manhajun Nabiyy Fid-Da'wah, seri terjemah oleh Anis Maftukhin dan Nandang Burhanuddin, Manhaj Dakwah Rasulullah, Jakarta; Qisthi Press, 2005.

Ahmad, Amrullah. Strategi Dakwah Islam di Tengah Era Reformasi Menuju Indonesia Baru dalam Memasuki Abad ke-21. Makalah pada sarasehan nasional: "Menggagas Strategi Dakwah Menuju Indonesia Baru." SMF Dakwah IAIN Sunan Gunung Djati, Bandung, 21 April 1999.

Bungin, Burhan. 2006. Sosiologi Komunikasi: Teori, Paradigma, dan Diskursus Teknologi Komunikasi di Masyarakat. Jakarta: Kencana.

David O. Sears dan Jonathan L. Freedman dan L. Anne Pepleu. Psikologi Sosial, PT Gelora Aksara Pratama, 1985

Dianto, Icol. Peranan Dakwah dan Pengembangan Masyarakat Islam, Jurnal Hikmah, 12 (1), Juli 2018.

Hamka, Prinsip dan Kebijaksanaan Dakwah Islam, Jakarta; PT Pustaka Panjimas, 1984.

https://minanews.net/umat-yang-satu/ diakses pada 3 April 2019, pukul 14.47 WIB.

https://muslimafiyah.com/para-sahabat-saling-memberi-syafaat-di-hari-kiamat.html diakses pada 3 April 2019 pukul 14.58 WIB.

Raji Fauzi dalam situs id-id.facebook.com/notes/raji-fauzi, diakses 3 April 2019, pukul 13.00 WIB.

Machendrawati dan Agus, Pengembangan Masyarakat Islam: Dari Ideology, Strategi, Sampai Tradisi, Bandung; PT Remaja Rosdakarya, 2001.

Mulkhan, Abdul Munir. Ideologisasi Gerakan Dakwah: Episode Kehidupan M Natsir dan Azhar Basyir, Yogyakarta, Sipress, 1996.

..... Ideologisasi Gerakan Dakwah, Yogyakarta, Sipress, 1999.

Shihab, M. Quraish. 2007. Membumikan Al-Quran Cet. II. Bandung: PT Mizan Pustaka.

Sulasmi, Siti. Peran Variabel Perilaku Belajar Inovatif, Intensitas Kerjasama Kelompok, Kebersamaan Visi dan Rasa Saling Percaya dalam Membentuk Kualitas Sinergi, Ekuitas, 13 (2), Juni 2009.

Wati, Kartika Sunu. Modal Dalam Praktik Sosial Arisan Sosialita, Jurnal Idea Societa, 2 (5), Oktober 2015.

Wulandari, Tika. Pola Komunikasi Komunitas Kaskus Regional Riau Raya dalam Membentuk Kohesivitas Kelompok, Universitas Riau, 2014, hlm. 6. http://jom.unri.ac.id diakses pada Selasa, 5 Maret 2019. 